above. Heilman and Herrell found that penicillin cured mouse infections with $S p$. minus and Strept. moniliformis, so that both forms of rat-bite fever may prove susceptible to it. The former responds dramatically to organic arsenicals, but the latter resists arsenic, sulphonamides and gold treatment. F. F. Kane (Lancet, 548, Oct. 21, 1944) reports on the infection of an Ulster boy with Strept. moniliformis as the result of a rat-bite, which was successfully treated with penicillin after gold treatment had failed. Eagle and Magnuson obtained cures with penicillin of infections of rats and mice with Spirochoeta recurrentis (=Treponema novyi), so that it is possible that penicillin may prove better than arsenic for the treatment of relapsing fever of man, which is caused by this organism.

G. LAPAGE.

\section{FORESTRY AND THE PUBLIC WELFARE}

$\mathrm{A}$ $T$ the autumn general meeting of the American Philosophical Society held in the hall of the Society on November 17-18, 1944, the first day was devoted to a symposium on "Forestry and the Public Welfare", brief papers being read (among others) on forests in relation to soils and water (Raphael Zon); world-wide needs of woods (W. C. Lowdermilk), public control of eutting practices on private timberland (Joseph F. Kaylor), and forest conservation-public and private co-operation (Wilson Compton).

Zon's research work in connexion with forests, soils and water is well known. He gave a brief summary of important points. The longer precipitation remains in circulation over the land before, as run-off, it reaches streams and ocean, the greater its use to the land. The greatest effect of forests upon water is therefore that they tend to prolong this water-cycle on and in the soil. In deep soils a large reservoir of ground water is retained which only gradually but regularly feeds the streams, thus preventing exceptional high rises resulting in floods, or low levels which diminish agricultural supplies. The protective cover of the forest reduces wind damage, decreases evaporation from the soil, reduces the temperature of the air and soil within the forest during the summer and raises it in winter. Growing trees transpire and thus increase the humidity of the air over forests, while their roots stabilize the soil.

Lowdermilk, in discussing the world-wide needs of woods, pointed out that man has grown up with wood, that he has always utilized the substance in the past, and human progress, in spite of the many substitutes, demands ever larger amounts. Wood, he said, is "a natural wonder of chemistry and physical structure" ; but cellular structure and chemical content of cell cavities give rise to a wide variety and many properties that serve hundreds of uses, even to paper and clothing fabrics. Modern technology has by special treatment of impregnation and compression produced new materials from wood that compete with metals. Chemical industries are opening up amazing possibilities in deriving from wood as raw material new chemicals based on fermentation of carbohydrates, even to the making of alcohol for rubber manufacture. On the subjects of demand, Lowdermilk said that the production of wood, reported as some 1.2 billion tons, is second only to that of fossil carbonized wood as coal, namely, 1.3 billion tons, and is practically tenfold that of steel.
America has long halted at the cross-roads of State interference in any way with the operations of the lumberman; enormous areas have been felled without a thought to the future, while fire has destroyed additional large areas of virgin forest. In his paper on public control of private felling, Kaylor said that within the last few years sentiment in many parts of the United States has veered strongly towards some form of public control of private fellings, the cumulative results of the unrestricted cuttings of the past now being more fully realized. A difference of opinion exists as to whether such control should be exercised by the individual States or by the Federal Government. Kaylor spoke for Maryland, stating that in 1943 the legislature of the State passed the Forest Conservancy Districts Act authorizing a Commission of State Forests and Parks to draw up rules of forest practice for all the privately owned forests of the State-certainly a move in the right direction.

Dealing with public and private co-operation in forest conservation, Wilson Compton discussed briefly the exploitation of the forests in the past and the results of surveys of the forests still existing in parts of the United States and the work of conservation now being carried out. The surveys showed that there are nearly a thousand tree farms comprising 10 million acres in the western and southern States, and the number is being constantly added to. In 1941 the National Lumber Manufacturers' Association co-operated with the forestry departments of thirtyseven States in a survey of 153 million acres of privately owned timber lands- the so-called industrial forest lands; of these, 25 million acres were under working plans, 45 million under less intensive management, another 73 million acres with reasonably satisfactory reproduction, but not adequately protected from fire. In other words, about 94 per cent of the area surveyed was considered to be in a "reasonably productive condition". When the total disregard shown for the immense forest estate exploited by the United States for so long, as if it were inexhaustible, is remembered, it is a good augury that the lumber companies, and to some extent the private forest owner, should have realized where unchecked exploitation was leading the country and its important industries.

\section{FORTHCOMING EVENTS}

(Meeting marked with an asterisk * is open to the public)

Monday, April 16

ROYAL SOCIETY of ARTS (at John Adam Street, Adelphi, London, W.C.2), at 1.45 p.m. - Sir Frank Smith, G.C.B., G.B.E., F.R.S. "Chemicals from Petroleum" (Cantor Lectures, i).

FARMrars' CuUB (at the Royal Empire Society, Craven Street, Strand, W.C.2), at 2.30 p.m.-Mr. H. W. Grimmitt: "Present and Future Aspects of Electricity in Agriculture".*

association of Austrian ENgINGme, Chemists and Screntific WORKERS IN GREAT BRITAIN (CHEMICAL GROOP) (at the Austrian Centre, 69 Eton Avenue, Hampstead, London, N.W.3), at 7.30 p.m... Mr. E. Chilton : "Present-day Problems of Industrial Photography". ROYA GeOGRAPHICAL SOCIETY (at Kensington Gore, South Kensington, London, S.W.7), at 8 p.m.-Dr. H. L. Richardson: "Szechwan ton, London, $\mathrm{S}, \mathrm{W}$

Tuesday, April 17

InSTITUTION OF NAVAL ARCHITECTS (at the Institution of Mechanical Engineers, Storey's Gate, St. James's Park, London, S.W.1), at 10.30 a.m.-Admiral of the Fleet the Rt. Hon. Lord Chatfield, G.C.B., O.M. : Presidential Address ; Sir Amos L. Avre, K.B.E.: "Merchant Shipbuilding during the War". At 4.30 p.m.-Mr. E. H. Watts: "Crews' Accommodation in Tramp Ships"; ; Mr. A. J. Sims : "The Habitability of Naval Ships under Wartime Conditions".

ROYAI SOCIETY OF ARTS (DOMINIONS AND COLONIES SEOTION) (at John Adam Street, Adelphi, London, W.C.2), at 1.45 p.m.Dr. Charles Camsell : "The New Programme of Fleld Investigation in the Canadian North-West". 